International Journal of

Advanced Science and Convergence

\title{
Perceived Relevance of Grade 9 Mathematics Topics to Everyday Life: Inputs to Context-based Enrichment Activities
}

\author{
John Patrick S. Alcantara ${ }^{1}$, John Christian E. Isip ${ }^{1}$,Gerardo R. Sison, Jr. ${ }^{1}$, Allan A. \\ Yutoc $^{1}$, Butch Stephen C. Duay ${ }^{1}$ and Rexella M. Umoquit ${ }^{1}$ \\ ${ }^{1}$ Bulacan State University, Malolos City, 3000, Philippines
}

\begin{abstract}
Background/Objectives: This research aspires to develop context-based enrichment activities that will make an interrelation between the concepts taught in Grade 9 Mathematics in Angat National High School at Taboc, Angat, Bulacan to the lives of the students. Methods/Statistical analysis: The sample of the study included 35 students. Contextual Teaching and Learning (CTL) approach can be used to address this study. Using the survey questionnaires, results revealed the topics that has perceived low relevance to the students were, law of sine, law of cosine, angle of elevation and depression, quadratic inequalities, applications on quadratic function, equations transformable into quadratic equation, oblique triangles, trigonometric ratios and special angle, solving quadratic equations by completing the square and graphs of quadratic function, and these are the topics contained in the enrichment activities. Findings: The students also replied that there is a need to come up with an instructional material that will connect these concepts to their lives and to improve their knowledge, abilities and skills, to monitor their assimilation of information, and to contribute to their overall development and upbringing. Improvements/Applications: The evaluation of the instructors to the enrichment activities scored an admissible mark and was complimented as useful and applicable.
\end{abstract}

Index Terms

context-based, enrichment activities, mathematics, contextual

Corresponding author : Butch Stephen C. Duay

butchoi.duay26@gmail.com

- Manuscript received April 12, 2020.

- Revised May 21, 2020 ; Accepted June 20, 2020.

- Date of publication June 30, 2020.

(1) The Academic Society of Convergence Science Inc.

2619-8150 () 2019 IJASC. Personal use is permitted, but republication/redistribution requires IJASC permission. 


\section{INTRODUCTION}

Mathematics can be considered part of life, it encompasses anyone's life at any age, profession, and circumstances. Counting age, calculating change, counting scores in exam, building establishments, measuring amount of medicines and days in the calendar are some significance of Mathematics in man's living. Mathematics is commonly considered as a difficult course with little interest to certain people. It niches an importance over and above the application of basic numeracy in that way; it will be the best instrument for developing student's logical thinking and higher-order cognitive skills. Teachers must be focused to get the attention on the less interested students as well as the motivated ones, they should maximize engagement and motivate the students to actively be involved in class. Generally, Mathematics is complex, it must be taught and learned comprehensively that can lead to the development of enduring knowledge to solve mathematical problems and situations.

Encountering problems or challenges in teaching Grade 9 Mathematics is not a new thing for a lot of Mathematics teachers. These are the challenges identified by some of Mathematics teachers whenever they are teaching Grade 9 Mathematics. There are five level of challenges that teachers perceived and these are: teacher professional development and pedagogical skills, student learning needs, settlement issues and family's social and economic background, administrative difficulties and resources, and curricular issues. These challenges are complex and interconnected, demanding special efforts by the teachers.

There are myriad methods to teach Mathematics, but one of these is traditional, where the teacher's based only in the books, and the only center of information in the class discussion. They use a daily routine where the teachers give an assignment before the end of the class and will check it before another class will start, after class discussion, where the teacher give one to two examples for that topic and afterwards a seatwork. So this is a traditional method in Math, the researchers don't imply that this is not effective, but rather assessed that students are just consumers of knowledge and there is little engagement in terms of relevant and responsive learning tasks that are appropriate to the setting of the students.

Contextual Teaching and Learning (CTL) approach can be used to address this study. Contextual learning simply implies a learners-based instructional strategy in which the learners are taught within the context they are familiar with to facilitate their understanding. CTL represents the use of events from students' and teachers' life, social and cultural background as a platform to learn the concept [1].
Additionally, CTL is an approach that is used to discover meaning by allowing the students to connect the content of the academic subjects with the immediate context of their daily lives [2]. Moreover, CTL can also be defined as a system of instruction based on the philosophy that students learn when they see meaning in academic material, and they see meaning in school work when they can connect new information with prior knowledge and their own experience and environment [3]. Contextual approach in teaching Mathematics gives meaning to concepts by emphasizing the relationship of each topic to everyday living. If the student understands the connection of a concept within the context of his life then they will find the significance or importance of lesson to them. Students in this approach will not only gain essential knowledge but also broaden their idea of the concepts to their daily lives, to the community and society, and most especially in their chosen field [2].

On the other hand, enrichment activities are described as higher quality of work than the norm for the age or group [4]. Additionally, this type of activity is covered in more depth and is used to broaden the learning experience. Another purpose of such activity is to promote a higher level of thinking as well as the inclusion of additional subject areas or activities. In addition, the Westminster Institute of Education defined enrichment activities in 2006 as tasks that involve problem solving, creative thinking, initiative and self-direction, discovery, higher order thinking skills, performed personal interests, self-acceptance and the courage to be different. This study includes these literatures of enrichment activity, since this is the type of activity that will be the medium for the content of the context-based activities. From this, the inclusion of contextual approach is somehow parallel to the purpose of providing enrichment activities to Grade 9 Mathematics subject which is to bring the lessons in real life context and to make it more lifelong.

This study focuses on the challenge of constructing context-based enrichment activities that make connections between the concepts taught in the Grade 9 Mathematics topics and how will the students apply each lesson to their daily lives. Comparing to the traditional method, that is also effective, context based enrichment will give time to students to reflect the lesson on their daily lives and their environment.

Mathematics is the key to opportunity. The field of mathematics now contributes in direct and fundamental ways to business, finance, health, and defenses. There is a vast career that students can look into the field of mathematics. It was suggested that good mathematics teachers should possess apart from basic content knowledge, a substantial amount of specialized knowledge which is known as pedagogical content knowledge [5]. Context-based enrichment activities within mathematics can be 
powerful sites for the development of mathematical understanding of Grade 9 students. Students ought to master mathematical concepts within the context during which they naturally arise from, easy investigation and activity to applications in real-life things.

\section{RESEARCH MODEL}

\section{A. Methods,Techniques, Population and Instrument}

This study employed the mixed method design involving qualitative data collection and analysis to help explain the quantitative data. The purpose of this mixed method study was to know the development of context-based enrichment activities in Grade 9 Mathematics topics using quantitative and qualitative data.

To examine the student perception of utilization of context-based enrichment activities, the quantitative analysis was formed through survey question in Grade 9 Mathematics module. The qualitative analysis is in the form of question, the students are asked whether there is a need to develop a new instructional material that will connect concept in Grade 9 Mathematics topics to their lives. In this process, the perception gave an in-depth explanation regarding the contextbased enrichment activities by connecting both methods for an overall complete understanding.

This study employed a stratified random sampling technique, utilizing $95 \%$ confidence interval and 0.05 margin of error. The population composed of three (3) sections in grade 9: 30 students from 9-Kindness, 27 students from 9-Respectfulness and 35 students from 9-Happiness in Angat National High School at Taboc, Angat, Bulacan with a total population of 120 students. The students who are currently taking the Grade 9 Mathematics subject in this school year 2018- 2019 were the sample because they already took the subject content and they are familiar with it.

The instrument used was a researcher-made questionnaire includes a need analysis that is constructed which includes the perceived relevance of the course contents present in the curriculum guide to the lives of the respondents. Moreover, it also includes the perception of the students of the need to develop a context-based instructional material that will connect concepts to their daily lives. The main purpose of this survey questionnaire is to find out the top 10 topics in grade 9 Mathematics that the students think has a very low relevance or low relevance in the daily living. The administration of the need analysis questionnaire took 20 minutes to complete. It focuses on two areas; first part is a self-rating of the perceived relevance of the contents of Grade 9 Mathematics to the lives of the respondents and this part is introduced with a question: "How do you find the relevance of the following course contents you have learned in Grade 9 Mathematics to your life out of school or to the society in general. The second part of the need analysis questionnaire includes a question that were answered by the students about their perceived need of having context-based instructional material to keep concepts in context and the question read and this part is introduced with a question: "Is there a need to come up with an instructional material that will connect the concept taught in Grade 9 Mathematics to your daily living? Why or why not?

The two parts of the questionnaire served a unique purpose to this study. The first part gauged the perceived extent of relevance of each course content or topics in the syllabus and will also serve as a basis of selecting what topics will be included in the context-based enrichment activities in Grade 9 Mathematics. The top 10 topics that result very low relevance or low relevance to the perception of the students and instructors were the priority topics that the researcher included in the context-based enrichment activities. Conversely, the second part of the questionnaire sought to answer the perceived need of students to have instructional materials that will bridge the gap between the concepts learned in Grade 9 Mathematics to their lives and the basis of choosing contents with high perceived relevance to be included in the enrichment activities.

The part I consists of a checklist survey questionnaire that can be answered by putting a check mark $(\sqrt{ })$ on the box pertaining to the extent of relevance you choose: (1) Very low Relevance; (2) Low Relevance; (3) Moderate Relevance; (4) High Relevance; (5) Very high Relevance. The part II is a questionnaire includes a question that can be answered by giving students own opinion or perception about their perceived need of having a context-based instructional material to keep concepts in context and the question read.

In the validation of the context-based enrichment activities in mathematics, a face validity is incorporated [2]. The purpose of the face validity, served its rationale of appraising whether the objectives are attainable; the contents are adequate and the relevance of the use of contextual approach to each enrichment activity. The study adapted the instrument utilized in evaluating the objectives and the content of the enrichment activity [6]. Descriptive measures were applied to guide the respondents throughout the evaluation. Moreover, Descriptive measures for the evaluation of the use of CTL in the enrichment activities were based on the following characteristics: (1) emphasizes problem solving; (2) 
recognizes the need for teaching and learning to occur in multiple contexts; (3) teaches students to become self-regulated learners; (4) anchors teaching in student's diverse life contexts; (5) encourage students to learn from each other in independent groups; and (6) employ authentic assessment [7].

\section{B. Data Gathering Procedure and Processing}

Data gathered from answered questionnaires was checked, revised, tabulated and analyzed according to the research design using qualitative and quantitative method.

Prior to this, the study was conducted to ninety two (92) Grade 9 students who have taken up their Mathematics 9 during the academic year 20182019 as well as ten (10) instructors of Bulacan State University-Bustos Campus who are M.A. Ed graduates.

The questionnaire was distributed to ninety two (92) students during their enrolment period and was also submitted on the same day, February 28, 2019. The researcher secured a letter requesting permission to conduct research and study to the Dean of Bulacan State University- Bustos Campus. The result of the survey aided the researcher to assess the topics that are needed to be included to the enrichment activities and to measure the students' perception of a need to develop a context-based instructional material. Moreover, the result of the need analysis administered to instructors validated the student's results. To further justify the result of the study conducted to the students and instructors, supplementary interviews was conducted.

The result of both quantitative and qualitative measurements of their perception of the relevance of the course contents in the Curriculum and Learner's Module are determining factors to which topics are included in the construction of the context-based enrichment activities. In the course of the study references from Math books and other related references were consulted. Further study about contextual teaching and learning approach was done, thru related literatures, to ensure that the enrichment activities included employed context-based techniques. Furthermore, to test the validity of the proposed context-based enrichment activities, a face validation was administered to ten (10) instructors from the University. The result of the face validation aided the researcher to consider some revisions and argumentations before the final product is presented. The suggestions and revisions made by the adviser and critic were highly considered to better improve the enrichment activities.

Descriptive statistics was used to summarize the data collected in the needs analysis and evaluation of the manual. For the need analysis, measures of central tendency was employed and the weighted average score of each content in the syllabus with regards to the perceived relevance of the students to their daily lives was obtained. Descriptive measures were applied to guide respondents throughout the evaluation and they will have to answer on a five point scale.

Similar treatment was utilized to get the weighted average of the perception of instructors to the relevance of each topic in the syllabus to the lives of the students. Both the computed mean as to the level of perceived relevance of the students and instructors were considered and the average of both results was obtained to came up with a list of the topics ranked from moderately relevant to highly relevant. Ten (10) contents of the syllabus with the lowest weighted average score in terms of the perceived relevance of the students and instructors to their lives are considered as priority topics to be included in the developed context-based enrichment activities in Grade 9 Mathematics. In addition, same statistical procedure was conducted in the validation of the content, objective and the use of contextual approach of the proposed context-based enrichment activity. Descriptive measures were used to guide the respondents throughout the evaluation and they will have to answer on a five-point scale where the range is:

$$
\begin{array}{lc}
\text { Very high relevance }-4.21-5.0 \\
\text { High relevance - } & 3.41-4.20 \\
\quad \text { Relevant - } & 2.61-3.40 \\
\text { Low relevance - } & 1.81-2.60 \\
\text { Very low relevance - } & 1.00-1.80
\end{array}
$$

Answers and responses to the questionnaires were coded, tabulated and analyzed using the frequency or the actual number of the respondents in the study. The verbal interpretation is concluded by computing the weighted mean. The weighted average of each descriptive measure was computed and the interpretation of it reflected the agreement of the instructors to the validity of the developed enrichment activities.

\section{RESEARCH RESULTS}

\section{A. Figures and Tables}

The perceived relevance of students of Grade 9 Mathematics to everyday life is used to measure how topics in Grade 9 Mathematics are significant to their lives and chosen careers. It was determined by a five point scale from very low relevance to high relevance of each topic to their daily lives.

Table 2 presents the descriptive measures and frequency distribution of the perceived relevance of 
ninety two (92) Grade 9 students of the topics in Mathematics to their daily lives.

The table presents the mean of every topic in the curriculum of Grade 9 Mathematics taken by the respondents. The result of the frequency distribution serves as a need analysis and a basis for determining the topics to be included in the context-based enrichment activities.

Table 1. FreQuency Distribution AND DESCRIPTIVE Measures of the Perceived Relevance of Grade 9 STUdents OF MATHEMATICS TOPICS TO EvERYDAY LIFE

\begin{tabular}{|c|c|c|}
\hline Course Content & Mean & $\begin{array}{c}\text { Verbal } \\
\text { Interpretatio } \\
\mathrm{n}\end{array}$ \\
\hline $\begin{array}{l}\text { Solving quadratic equations by } \\
\text { extracting square roots }\end{array}$ & 2.71 & $\mathrm{R}$ \\
\hline $\begin{array}{l}\text { Solving quadratic equations by } \\
\text { factoring }\end{array}$ & 2.72 & $\mathrm{R}$ \\
\hline $\begin{array}{l}\text { Solving quadratic equations by } \\
\text { completing the square }\end{array}$ & 2.41 & LR \\
\hline $\begin{array}{l}\text { Solving quadratic equations by } \\
\text { using the quadratic formula }\end{array}$ & 2.65 & $\mathrm{R}$ \\
\hline $\begin{array}{l}\text { The nature of the roots of a } \\
\text { quadratic equation }\end{array}$ & 2.38 & LR \\
\hline $\begin{array}{l}\text { The sum and the product of roots } \\
\text { of a quadratic equation }\end{array}$ & 2.67 & $\mathrm{R}$ \\
\hline $\begin{array}{l}\text { Equations transformable into } \\
\text { quadratic equations }\end{array}$ & 2.32 & LR \\
\hline $\begin{array}{l}\text { Solving problems involving } \\
\text { quadratic equations }\end{array}$ & 2.57 & LR \\
\hline Quadratic inequalities & 2.24 & LR \\
\hline Quadratic functions & 2.49 & LR \\
\hline Graphs of Quadratic Functions & 2.42 & LR \\
\hline $\begin{array}{l}\text { Finding the equation of a } \\
\text { quadratic function }\end{array}$ & 2.48 & LR \\
\hline $\begin{array}{l}\text { Applications of quadratic } \\
\text { functions }\end{array}$ & 2.30 & LR \\
\hline Direct Variation & 2.92 & $\mathrm{R}$ \\
\hline Joint Variation & 2.74 & $\mathrm{R}$ \\
\hline Combined Variation & 2.83 & $\mathrm{R}$ \\
\hline $\begin{array}{l}\text { Zero, Negative and Rational } \\
\text { Exponents }\end{array}$ & 2.87 & $\mathrm{R}$ \\
\hline Radicals & 2.84 & $\mathrm{R}$ \\
\hline Solving Radical Equations & 2.59 & LR \\
\hline Quadrilaterals & 2.91 & $\mathrm{R}$ \\
\hline Similarity & 2.83 & $\mathrm{R}$ \\
\hline The Six Trigonometric Ratios & 2.58 & LR \\
\hline $\begin{array}{l}\text { Trigonometric ratios of special } \\
\text { angles }\end{array}$ & 2.39 & LR \\
\hline $\begin{array}{l}\text { Angles of elevation and angle of } \\
\text { depression }\end{array}$ & 2.22 & LR \\
\hline $\begin{array}{l}\text { Word problems involving right } \\
\text { triangles }\end{array}$ & 2.47 & LR \\
\hline Oblique Triangles & 2.34 & LR \\
\hline The Law of Sines & 2.15 & LR \\
\hline The Law of Cosines & 2.16 & LR \\
\hline $\begin{array}{l}\text { Applications of Law of Sines and } \\
\text { Cosines }\end{array}$ & 2.46 & LR \\
\hline
\end{tabular}

The result in Table 1 manifests that the topic with the lowest mean of 2.15 which in turn descriptively marked has low relevance to their daily lives is the topic of law of sine. It was found out that the topic next to law of sine is law of cosines (2.16), Angle of elevation and depression (2.22), quadratic inequalities (2.24), applications on quadratic function (2.30), equations transformable into quadratic equation (2.32), oblique triangles (2.34), trigonometric ratios and special angles(2.39), solving quadratic equation by completing the square (2.41) and graphs of quadratic function (2.42).

Law of cosines, law of sine and angle of elevation are the top three of the topics that is least relevant to the lives of the student. It clearly shows that the student finds Trigonometry as the most difficult subject in Mathematics and they cannot appreciate the importance or relevance of the trigonometry lesson to their daily lives. These topics are well understood by the student if there is enough time for them to analyze, compute and memorize the formulas if necessary.

A study pointed out the types of things we might think about a mathematics classroom are equations, procedures, and word problems, but in learning them, a student needs to master to solve problem . Thus, over the last number of decades there has been a move to approach the teaching of arithmetic through problem-solving. Problem-solving as outlined within the wordbook is that the thought processes concerned in resolution a problem and it is conjointly the world of psychology that studies the processes concerned in solving problems [8].

As an output of this study, the researcher provided an enrichment activity to supplement the understanding of the student to the topic that is least relevant. Each of the ten topics given at the Table 1 with a Low relevant verbal interpretation is given an activity for the students to answer. They must then scan the matter carefully, analyze it for whatever information it has, and examine their own mathematical knowledge to see if they can come up with a strategy that will help them find a solution. The process forces the reorganization of existing concepts and also the emergence of latest ones as students work on issues with the assistance of a coach who acts as a facilitator by asking queries that facilitate students to review their data and construct new connections.

Most of the topics listed are all about quadratic functions and equations. There seems to be agreement in the field that when solving equations, students tend to use procedures without understanding and that students have difficulties with aspects of solving quadratic equations such as factoring, applying the zero-product property, and solving equations that are not in general form [9]. In an analysis of textbooks in Sweden, it was found out that when students learn to solve quadratic equations, they are taught to memorize and enact rules and procedures with little understanding of the meaning of the quadratic equations or what the solutions they find might mean [10]. Sönnerhed's finding fits well with categorization of being able to memorize and apply rules as 
instrumental understanding, and knowing what to do and why as relational understanding [11]. When students only memorize procedures, they may develop instrumental understanding while their relational understanding lags behind. In their analysis of student work on quadratic equations, it was found that students incorrectly tried to transfer rules from one form of an equation to another [9].

In addition to the descriptive measure of the relevance of these topics to the lives of the students, there were asked if there is a need to come up with an instructional material that will connect the concepts taught in their Mathematics 9 class to their lives. Majority of the respondents replied yes there is a need to develop a new instructional materials that will connect in Grade 9 Mathematics topics to their lives. There were several reason why these students agreed to come up with an instructional material that is context-based.

The students replied with the following reasons:

(1.) "Oo dahil mas makakaganda kung mas pinaiintindi sa estudyante ang mga ginagawa sa paaralan upang masagot din nila ito ng maayos." (2.) "Yes, para mas maintindihan pa namin ang pag-aaral sa Math minsan kasi nakakalito o kaya minsan ay hindi namin ma-gets kung paano nakuha ang tamang sagot." (3.) "Yes, kailangan po ng Instructional materials para po mas maintindihan pa lalo ang mga tinuturo ng teacher, at syempre sabayan din ng tanong kung naintindihan ba o hindi." (4.) "Opo kailangan po natin ang mga instructional material katulad po ng mga visual aids kaya po kailangan ng instructional material ay para makuha ang mga student na makinig kasi nung wala ang mga instructional material ay walang mga student ang nakikinig. Kaya po ang mga guro ngayon ay nage-effort po sila gumawa ng mga video o visual aids ay para po makayanan na makinig ang mga student katulad ng mga movie na pinapanuod at may mababasa rin ang mga student." (5.) "Yes, because we can easily understand the lesson if there's an instructional material that can connect to our topic." (6.) "Yes because it helps them to summarize which solution they need to know well, and it can help them to understand more by reading it again and can help also tell them which is correct or not." (7.) "Yes dahil hindi lahat sa kaalaman ng tao ay madaling matuto ng Math kung kaya't kailangan pa ng ibang instructional materials para higit na maunawaan o maipaintindi sa iba ang mga araling ito." (8.) "Yes, because it help us to understand clearly the lessons and topics." (9.) "Yes, because it will be easier to understand and to memorize formulas and other hard steps in solving. Also, to be more familiarize with mathematical vocabulary." (10.) "Depende po sa students or sa teacher kung naiintindihan naman po ng mga students kapag sa board lang okay lang po dahil mas maliwanag po sa board at maraming pwedeng ibigay na example. Pero kung medyo mahinang makaintindi yung students okay lang din na may visual aids. It depends naman po kung saan mas matututo at maiintindihan ng students."

The perceived relevance of the students to the Mathematics topics to their lives served as basis to what content should be included in the enrichment activities. "Teaching equipment and materials have changed over the years, not only to facilitate teaching learning situation but also to address the instructional needs of individuals and groups" [12]. The needs analysis can give a conception to what topics the students cannot elevate in their daily life and to what interests them. In this study, the question as to the need of coming up an instructional material in Grade 9 Mathematics that is context-based served as a need analysis and a basis of the construction of the contextbased enrichment activities. It is noticeable that from the answers of the students there is a need to come up with context-based enrichment activities that will connect concepts to the lives of the students.

Table 2. The Content In THE "Learner's Material Mathematics Grade 9" Perceived by the Students AS Low RELEVANT TO EVERYDAY LIFE AND INCLUDED IN THE CONTEXT-BASEd ENRICHMENT ACTIVITIES

\begin{tabular}{lll}
\hline \hline \multicolumn{1}{c}{ Course Content } & Mean & $\begin{array}{c}\text { Verbal } \\
\text { Interpretation }\end{array}$ \\
\hline & & \\
The Law of Sine & 2.15 & LR \\
The Law of Cosine & 2.16 & LR \\
Angle of Elevation and Depression & 2.22 & LR \\
Quadratic Inequalities & 2.24 & LR \\
Applications on Quadratic Function & 2.30 & LR \\
Equations Transformable into & 2.32 & LR \\
Quadratic Equation & & \\
Oblique Triangle & 2.34 & LR \\
Trigonometric Ratios and Special & 2.39 & LR \\
$\begin{array}{l}\text { Angles } \\
\text { Solving Quadratic Equation by }\end{array}$ & 2.41 & LR \\
Completing the Square & & \\
Graphs of Quadratic Function & 2.42 & LR \\
\hline
\end{tabular}

In table 3 , these are the topics that are included in the context-based enrichment activities. These are the average of the result of the needs analysis of student. These topic included since they have marked low relevant to the live of the respondents.

To analyze the result, this concept that marked low significant to the lives of the students is fundamental concepts in mathematics. This is taught in Grade 9 "Learner's Material Mathematics Grade 9". However, the researcher has found significance in enriching these topics in order for the learners to have enduring knowledge on these concepts for better 
understanding and preparation for the higher mathematics.

\section{RESULTS IN THE PROCESS OF DESCRIBING THE DEVELOPMENT OF CONTEXT-BASED ENRICHMENT ACTIVITIES IN GRADE 9 Mathematics}

The content of the topics in the context-based enrichment activities are described in terms of administering a need analysis and selection of the topics to be included in the survey questionnaire. The topics that have the lowest mark of "low relevance" should be part of the context-based enrichment activities. The researchers have to construct an activities using contextual approach and with the help of ten (10) instructors of Bulacan State University the objectives and content of the context-based enrichment activities are validated.

Table 3. Frequency DisTRIBUTION AND DESCRIPTIVE Measures OF THE VALIDITY OF THE OBJECTIVES AND CONTENTS OF THE CONTEXT-BASED ENRICHMENT ACtivities in Grade 9 Mathematics

\begin{tabular}{lcc}
\hline \multicolumn{1}{c}{ Descriptive Measures } & Mean & $\begin{array}{c}\text { Verbal } \\
\text { Interpretation }\end{array}$ \\
\hline $\begin{array}{l}\text { A. Objectives } \\
\text { 1. The objectives of each activity } \\
\text { are well defined. }\end{array}$ & 4.90 & Strongly Agree \\
$\begin{array}{l}\text { 2. The objectives are congruent to } \\
\text { the objectives of the frame. }\end{array}$ & 4.90 & Strongly Agree \\
B. Contents & & \\
$\begin{array}{l}\text { 1. The topics are relevant to the } \\
\text { needs of the learners. }\end{array}$ & 5 & Strongly Agree \\
$\begin{array}{l}\text { 2. The information presented is } \\
\text { accurate. }\end{array}$ & 4.60 & Strongly Agree \\
$\begin{array}{l}\text { 3. The language used is appropriate } \\
\text { to the learners. }\end{array}$ & 4.60 & Strongly Agree \\
$\begin{array}{l}\text { 4. The level of difficulty is } \\
\text { appropriate to the learners. } \\
\text { 5. The contents of the activities are } \\
\text { not too long nor too short. }\end{array}$ & 4.70 & Strongly Agree \\
6. The learning activities are \\
appropriate to the learners.
\end{tabular}

With the same instrument used in the study of Basilio (2006), the results in table four shows the strong agreement of 7 Mathematics Instructors and 3 Educational Technology Instructors from Bulacan State University (Bustos Campus) with the objectives and contents of the enrichment activities.

\section{VALIDITY OF THE USE OF CONTEXTUAL TEACHING AND LEARNING OF THE CONTEXT-BASED ENRICHMENT ACTIVITY IN GRADE 9 MATHEMATICS.}

Table 4 shows the result of the validity of experts with the implementation of the researcher of the contextual teaching and learning to the enrichment activities.
Table 4. Frequency Distribution AND DESCRIPTIVE

MEasures OF THE VALIDITY OF THE USE OF

CONTEXTUAL TEACHING AND LEARNING TO THE CONTEXT-BASED ENRICHMENT ACTIVITIES IN GRADE 9 MATHEMATICS

\begin{tabular}{lcc}
\hline \hline \multicolumn{1}{c}{ Descriptive Measures } & Mean & Verbal Interpretation \\
\hline $\begin{array}{l}\text { 1. The activities emphasize problem } \\
\text { solving. }\end{array}$ & 4.90 & Strongly Agree \\
$\begin{array}{l}\text { 2. The activities recognize the need } \\
\text { for teaching and learning to occur in } \\
\text { multiple contexts. }\end{array}$ & 4.90 & Strongly Agree \\
$\begin{array}{l}\text { 3. The activities teach students to } \\
\text { become self-regulated learners. }\end{array}$ & 5 & Strongly Agree \\
$\begin{array}{l}\text { 4. The activities anchor teaching in } \\
\text { student's diverse life contexts. }\end{array}$ & 4.70 & Strongly Agree \\
$\begin{array}{l}\text { 5. The activities encourage students } \\
\text { to learn from each other in } \\
\text { independent groups. }\end{array}$ & 4.70 & Strongly Agree \\
$\begin{array}{l}\text { 6. The activities employ authentic } \\
\text { assessment. }\end{array}$ & 4.80 & Strongly Agree
\end{tabular}

Contextual Teaching and Learning (CTL) Approach is an approach which helps students understand what they are learning by connecting their subject with their lives' context [3]. According to Lynch, 20 years of research on student learning, motivation and achievement confirm the importance of contextual teaching and learning, so that students will understand the meaning of their experiences and thus the meaning of their educators. Moreover, it was emphasized in a study the importance of evaluating the validity in terms of the content and the way the CTL materials are presented [13]. Meanwhile it was articulated the significance of evaluating the developed materials using contextual approach in terms of the content of the lesson, the development of mathematical skills and attitudes, how appropriate are the strategies used and its relevance to real life experiences [14]. These related studies are important basis of evaluation of the developed enrichment activities.

The above descriptive measures of the use of contextual teaching and learning are adapted to the definition of CTL by the Ohio State University in which it states that the effectiveness of the employment of CTL is based on it. From the results in table no. 5 the context-based enrichment activities passed with a strong agreement from 7 Mathematics Instructors and 3 Educational Technology Instructors in terms of the use of CTL. The impressions of the respondents to the enrichment activities were cited in the answered questionnaires. The instructors noted that the activities are very clear, appropriate and highly recommended. In addition, the enrichment activities are one of the appropriate ways to understand Mathematics subject. 


\section{CONCLUSION}

Based on the findings, the following conclusions were made:

1. The majority of the contents perceived with low relevance to the lives of the students are the topics included in their trigonometry and quadratic equation and function.

2. The topics in Grade 9 Mathematics that are included in the context-based enrichment activities are law of sine, law of cosines, angle of elevation and depression, quadratic inequalities, applications on quadratic function, equations transformable into quadratic equation, oblique triangles, trigonometric ratios and special angles, solving quadratic equation by completing the square and graphs of quadratic function.

3. The process that are involved in the development of the context-based enrichment activities are administering to be a need analysis, selection of the topics to be included in the activities, constructing the activities using contextual approach and validating the activities with the aid of Mathematics instructors.

4. Based on the results of the validity of the contextbased enrichment activities in Grade 9 Mathematics it is revealed that its objectives, contents and the use of CTL are applicable. The impression of the instructors with the context-based enrichment activities is remarkably good as they have found it interesting and contextual.

\section{ACKNOWLEDGMENT}

The authors would like to express their deepest gratitude to the principal, head teachers, faculty of Mathematics and the Grade 9 students of Angat National High School. Moreover, gratitude is given as well to the administrator and the faculty of research and math of Bulacan State University- Bustos Campus. Above all, we would like to thank our God Almighty, for his guidance and wisdom in making this scholarly work.

\section{REFERENCES}

[1] Tong (2014). A literature review on contextual learning. Benin City, Nigeria, 21-22

[2] Duay, B. S. C. (2017). Perceived Relevance of Chemistry Topics to Everyday Life: Inputs to Context Based Enrichment Activities in General and Inorganic Chemistry. International Journal of Emerging Multidisciplinary Research, 1(1), 2017th ser., 73-83. doi:10.22662/IJEMR.2017.1.1.073

[3] Johnson, Elaine (2002). Contextual teaching and learning: what it is and why it's here to stay. Thousand Oaks, CA: Corwin Press Inc
[4] Teare, J.B. (2004) Enrichment Activities for Able and Talented Children. Stafford: Network Educational Press

[5] Adedoyin, O. (2011). THE IMPACT OF TEACHERS' IN-DEPTH PEDAGOGICAL MATHEMATICAL CONTENT KNOWLEDGE ON ACADEMIC PERFORMANCE : AS PERCEIVED BY BOTSWANA JUNIOR SECONDARY SCHOOL PUPILS. . European Journal of Educational Studies, 3(2). Retrieved from http://agris.fao.org/agrissearch/search.do?recordID=TR2016003990

[6] Basilio, E. (2006). Construction and Evaluation of Modules in Selected Topics in Secondary Chemistry, Bulacan State University - Graduate Studies, Malolos City

[7] Wilson, M. And Clifford, M. (2000) Contextual Teaching, Professional Learning, and Student Experiences: Lessons Learned from Implementation. Center on Education and Work University of Wisconsin-Madison

[8] Hugar, D. (2011). TheRole of Problem Solving in the Mathematics Classroom. A Research Paper Methods. Retrieved http://www.lhup.edu/swillia6/MATH\%20200/

[9] Didiş, M., Baş, S., \& Erbaş, A. (2011). Students' reasoning in quadratic equations withone unknown. In Proceedings of the 7th Congress of the European Society for Researchin Mathematics Education. Rzeszów, Poland

[10] Sönnerhed, W. W. (2009). Alternative approaches of solving quadratic equations in mathematics teaching: An empirical study of mathematics textbooks and teaching material or Swedish Upper-secondary school. Retrieved from http://www.ipd.gu.se/ digitalAssets/1272/1272539_plansem_wei.pdf

[11] Skemp, R. (1976). Instrumental understanding and relational understanding. Mathematics Teaching, 77, 20-26.

[12] Ema (2004) Impacts of Instructional Material in teaching and learning biology in senior Secondary schools. (A case study of Sabuwar Kofa, Gwale Local Government Area of Kano State)

[13] Biag, S.C. " Development and Validation of Contextual Teaching and Learning Materials for Selected Mathematics of Investment", Tarlac State University, Tarlac City.,2003

[14] Belen, Irene. "Contextual Teaching Approach: An Alternative Approach in Teaching Chemistry" Bicol University, 2005 